\title{
Fructus Ligustri Lucidi modulates estrogen receptor expression with no uterotrophic effect in ovariectomized rats
}

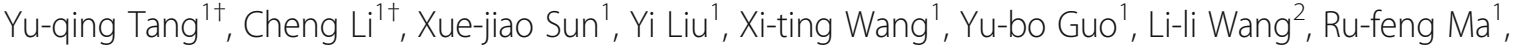 \\ Jian-zhao Niu', Min Fu', Dong-wei Zhang ${ }^{4^{*}}$ and $\mathrm{Yu} \mathrm{Li}^{\mathrm{i}^{*}}$
}

\begin{abstract}
Background: Accumulating evidence suggests that Fructus Ligustri Lucidi (FLL) plays a beneficial role in preventing the development of osteoporosis. However, the effects of FLL on estrogen receptor (ER) a and ER $\beta$ expressions remain unknown. Therefore, in the current study we attempted to probe into the effects of FLL on ERa and ER $\beta$ expressions in femurs, tibias and uteri of ovariectomized (OVX) rats.

Methods: The OVX rats were orally administrated with FLL water extract (3.5 g/kg/day) for 12 weeks. The uteri, femurs, tibias and serum were harvested from rats. The serum levels of estrogen $\left(E_{2}\right)$, luteinizing hormone $(\mathrm{LH})$ and follicle-stimulating hormone (FSH) were determined by ELISA. The expressions of ERa and ER $\beta$ in the femurs and tibias as well as uteri were analysed by western blot and immunohistochemical staining.

Results: FLL treatment did not increase uterus relative weight in OVX rats. Further, FLL treatment increased ERa expression in the femurs and tibias, and enhanced ERß expression in the uteri of OVX rats. However, the resulted expression of ERa was stronger than that of ERß in OVX rats in response to FLL treatment. Meanwhile,

administration with FLL to OVX rats increased FSH and LH but did not increase $E_{2}$ level in the serum.

Conclusion: FLL treatment shows tissue selection on ERa and ERß expressions in the femurs and tibias as well as uteri of OVX rats without uterotrophic effect, which may offer the scientific evidence of the efficiency and safety of its clinical application.
\end{abstract}

Keywords: Fructus Ligustri Lucidi (FLL), Osteoporosis, Estrogen receptor, Femurs, Tibias, Uteri

\section{Background}

As life expectancy around world shows dramatic rise in the last several decades, osteoporosis, one of common chronic metabolic diseases among the elders, has become a prevalent public health problem owing to its high morbidity and mortality [1]. According to the report from International Osteoporosis Foundation, women are at a higher risk of developing osteoporosis than men because of the estrogen deficiency after their menopause [2]. As such, classical hormone replacement therapy (HRT) is

\footnotetext{
* Correspondence: dongwei1006@gmail.com; liyubeijing1973@163.com ${ }^{\dagger}$ Equal contributors

${ }^{4}$ Diabetes Research Center, Beijing University of Chinese Medicine, Beijing 100029, People's Republic of China

'Traditional Chinese Medicine School, Beijing University of Chinese Medicine, Beijing 100029, People's Republic of China

Full list of author information is available at the end of the article
}

widely used to prevent both menopausal symptoms and osteoporotic fractures [3]. Estrogen promotes bone accrual through estrogen receptor (ER) $\alpha$ and ER $\beta$ [4]. In addition, deletion of ER $\alpha$ in female mice exhibits reduction of bone mass and strength $[5,6]$, whereas increased expression of ER $\alpha$ in endothelium is associated with risk of developing breast and uterine cancer, which are also main side effects induced by HRT treatment $[7,8]$. Moreover, selective activation of ER $\beta$ contributes to inhibition of breast cell proliferation and is also one of optimal targets to elicit beneficial estrogen-like activities $[4,9,10]$. Therefore, discovery and development of selective ER agonist remains a need for osteoporosis treatment.

Fructus Ligustri Lucidi (FLL) is the ripe fruit derived from the evergreen tree Ligustrum lucidum Ait. It is a common herbal medicine widely used in traditional 
Chinese medicine (TCM) formula for the management of osteoporosis [11]. FLL extracts have been demonstrated to improve bone quality in diabetic mice [12] and growing female rats [13] through regulation of calcium metabolism via stimulating parathyroid production. We [14] and others [15] also demonstrated that aqueous extracts of FLL improved bone mineral density (BMD) and bone microstructure in ovariectomized (OVX) rats via regulation of collagen metabolism. In addition, FLL ethanol extracts also promote mesenchymal stem cells differentiation [16]. However, little is known about the effect of FLL on ER expression in OVX rats. Therefore, the present study is aimed to explore the effects of FLL on ER $\alpha$ and ER $\beta$ expressions in the femurs, tibias and uteri as well as its effects on uterus weight in OVX rats.

\section{Methods}

\section{Reagents and chemicals}

Pentobarbital sodium was purchased from SigmaAldrich (St. Louis, USA), Estradiol valerate (EV) tablets were bought from Bayer (Monheim, German). Rat monoclonal anti-ER $\alpha$ antibody (ab3575) and mouse monoclonal anti-ER $\beta$ (ab288) were purchased from Abcam (Cambridge, UK). All the other chemicals, except specially identified, were obtained from Beijing Sinopharm Chemical (Beijing, China).

\section{Preparation of FLL water extracts}

FLL was bought from Beijing TongRenTang (Beijing, China) and authenticated by Professor Zexin Ma (TCM museum at Beijing University of Traditional Chinese Medicine (BUCM)). For preparation of FLL water extracts, $100 \mathrm{~g}$ of raw FLL was grinded into powder and dissolved in $1000 \mathrm{ml}$ of distilled water by continuous stirring for $48 \mathrm{~h}$ under low temperature. Then the aqueous extracts were collected by centrifugation (4000 rpm at $4{ }^{\circ} \mathrm{C}$ for $\left.10 \mathrm{~min}\right)$. And the supernatants were harvested and lyophilized to obtain a powder (20 g).

\section{Animals}

Female 12-week-old Sprague Dawley rats (200 $\pm 20 \mathrm{~g}$ ) were purchased from Beijing SiBeiFu Animal Technology company (license number: SCXK (Beijing) 20140037, Beijing, China). The animals were housed in the clean level conditions (certification number: SCXK (Beijing) 2011-0024) at BUCM with the temperature of $22 \pm 1{ }^{\circ} \mathrm{C}$, humidity of $55 \pm 5 \%$, and a $12 \mathrm{~h}$-light/dark cycle. All rats had free access to tap water and standard chow. All procedures in this study were approved by the Animal Care Committee of BUCM, Beijing, China.

\section{OVX rat model establishment}

After 1 week of acclimation, the OVX rats were established by removing the bilateral ovaries from the corresponding anesthetized rats. The sham control groups were performed by removing the equal volume of fat surrounding the bilateral ovaries. One week after surgery, the OVX animals were randomly divided into three groups of 9 rats in each, named OVX control, $\mathrm{OVX}+\mathrm{EV}$ and OVX + FLL, respectively. For the treatment, the rats in the OVX + FLL group were orally administrated with the water extracts of FLL $(3.5 \mathrm{~g} / \mathrm{kg} /$ day). The rats in the OVX + EV group were orally administrated with EV tablets $(0.1 \mathrm{mg} / \mathrm{kg} /$ day $)$. The rats in OVX control group and Sham control group were orally administrated with the same volume of distilled water.

After 12 weeks of administration, rats were anesthetized by intraperitoneal injection with $1 \%$ pentobarbital sodium (0.4 ml/100 g, i.p.). Subsequently, blood was collected from the heart by puncture. Then the rats were sacrificed by cervical dislocation. After that, the uteri, femurs and tibias were harvested for the following experiments.

\section{Uterus coefficient}

After trimming off the fat and absorbing the excess surrounding fluid, the wet weight of the uterus was recorded with analytical balance. Then, the uteri were cut into pieces just above the junction with the cervix. Half of the uteri were stored in liquid nitrogen until use. Another half of it was fixed in 10\% neutral buffered formalin for histological analysis. Uterus coefficient was determined by uterus wet weight divided by the corresponding body weight of the rat (g/100 g).

\section{Estrogen (E2), luteinizing hormone (LH) and follicle- stimulating hormone (FSH)}

$\mathrm{E}_{2}$, LH and FSH were determined by ELISA (CUSABIO, China) according to the manufacturer's instructions. All the samples were evaluated in duplicates.

\section{Immunohistochemical staining}

The femurs and uteri were fixed with 10\% neutral buffered formalin. Furthermore, the tibias were decalcified in $15 \%$ ethylenediaminetetraacetic acid (EDTA) buffer $(\mathrm{pH}$ 7.4) for 90 days. After that, the femurs and uteri were dehydrated in graded ethanol, defatted in xylene, and embedded in paraffin. Then, $5 \mu \mathrm{m}$ sections were deparaffinized in xylene and rehydrated with graded ethanol. Subsequently, the sections were incubated with $3 \% \mathrm{H}_{2} \mathrm{O}_{2}$ and antigen retrieval solution $(0.1 \mathrm{M}$ sodium citrate buffer, $\mathrm{pH}$ 6.0) followed by incubation with $10 \%$ goat serum in phosphate-buffered saline (PBS) for 30 min to block nonspecific binding sites. The sections were then incubated with the primary antibodies (antiER $\alpha$ antibody (1:500) or anti-ER $\beta$ antibody (1:500)) overnight at $4{ }^{\circ} \mathrm{C}$. The next day, after washing in PBS, the sections were incubated with biotinylated anti-rat secondary antibody for $30 \mathrm{~min}$ and with peroxidase for 
10 min according to the SP staining system (Beijing ZhongShan JinQiao, Beijing, China). Diaminobenzidine (DAB) was used as the substrate for color development and visualization under the microscope. For controls, the primary antibodies were replaced by non-immunized goat serum. The slides were then taken for histopathological evaluations. The results of immunohistochemical staining were quantified by Image Pro-Plus software (version 6, SPSS Inc., Chicago, IL, USA) and the integral optical density (IOD) values were recorded. The measurements were performed by two investigators who were blinded regarding the animals' treatment groups.

\section{Western blot analysis}

The uteri were placed in a $1.5 \mathrm{ml}$ Eppendorf tube and washed with PBS twice, and then were cut with scissors and grounded. The tibias were prepared by lyophilizing and grinding. After that, the samples were lysed in a buffer containing $20 \mathrm{mM}$ Tris $-\mathrm{HCl}, \mathrm{pH} 7.5,0.1 \%(\mathrm{v} / \mathrm{v})$ Igepal, $6 \mathrm{mM}$ sodium deoxycholate, $150 \mathrm{mM} \mathrm{NaCl}$, $2 \mathrm{mM}$ ethyleneglycoltetraacetic acid (EGTA), $2 \mathrm{mM}$ EDTA, $0.1 \mathrm{mM} \mathrm{Na}_{2} \mathrm{SO}_{4}, 20 \mathrm{mM} \mathrm{NaF}$, and a protease inhibitor cocktail tablet (Roche, German). The lysates were centrifuged at $10,000 \mathrm{~g}$ for $15 \mathrm{~min}$ at $4{ }^{\circ} \mathrm{C}$, and protein concentrations in the supernatants were determined by BCA protein assay kit (Applygene, China). Then $50 \mu \mathrm{g} / \mathrm{lane}$ of proteins were loaded into $10 \%$ polyacrylamide gel, and transferred onto nitrocellulose membrane, and then incubated with the primary antibody (anti-ER $\alpha$ or anti-ER $\beta$ ) and the corresponding HRP labeled secondary antibody. The membranes were developed using enhanced chemiluminescence solution. The images were captured with Bio-Rad bioimaging system. The gray values of the blots were quantified using the Image J software $(\mathrm{NIH}$, Bethesda, $\mathrm{MD})$, and normalized with the corresponding $\beta$-actin (1:2000) as the internal control.

\section{Statistical analysis}

Data were expressed as the mean \pm standard deviation (SD). One-way analysis of variance (ANOVA) was performed between multiple groups using SPSS software (Version 20.0) when homogeneity of variance and normality were met. Otherwise, Dunnett's T3 and Nonparametric tests were conducted between multiple groups, respectively. $P$ values less than 0.05 were considered to be statistically significant.

\section{Results}

\section{Effects of FLL on the alterations of uterus coefficient in} OVX rats

The uterus coefficient of the rats were shown in Table 1. As expected, ovariectomy resulted in a significant reduction in the relative uterus weight of the rats. The uterus
Table 1 The uterus coefficient in the different groups of rats

\begin{tabular}{lll}
\hline Groups & Number & Uterus weight/Body weight $(\mathrm{g} / 100 \mathrm{~g})$ \\
\hline Sham & 9 & $0.2132 \pm 0.0312^{*}$ \\
OVX & 9 & $0.0357 \pm 0.0143$ \\
OVX + EV & 9 & $0.1493 \pm 0.0240^{*}$ \\
OVX + FLL & 9 & $0.0322 \pm 0.0137$ \\
\hline
\end{tabular}

*Compared with OVX group rats, ${ }^{*} P<0.05$

coefficient in the OVX control group was only around $16 \%$ of that in the Sham control group. EV treatment for 12 weeks significantly increased the uterus coefficient in OVX rats $(P<0.05)$. By contrast, FLL treatment did not increase the uterus coefficient in OVX rats.

\section{Effects of FLL on $E_{2}$, LH and FSH levels in serum}

As shown in Table 2, serum $E_{2}$ level was decreased, and serum LH and FSH levels were increased in the OVX control group rats as compared to those of rats in the Sham control group. The administration of EV and FLL to OVX rats for 12 weeks significantly decreased serum LH and FSH levels $(P<0.05)$. However, FLL treatment did not increase serum $\mathrm{E}_{2}$ in OVX rats $(P>0.05)$.

\section{Effects of FLL on the expressions of ERa and ER $\beta$ in the femurs and tibias of OVX rats}

The effects of FLL on ER $\alpha$ and ER $\beta$ expressions in the femurs were assessed by immunohistochemical staining. As shown in Figs. 1 and 2, ER $\alpha$ and ER $\beta$ expressions in the femurs of the OVX control group were significantly decreased $(P<0.01)$, when compared with those of rats in the Sham control group. Both FLL and EV treatment significantly increased ER $\alpha$ and ER $\beta$ expressions in the femurs of the OVX rats $(P<0.05$ or 0.01$)$ when compared to those in the OVX control group.

Furthermore, the effects of FLL on ER $\alpha$ and ER $\beta$ expressions in the tibias of the rats in different groups were also evaluated by western blot. As shown in Fig. 3, FLL treatment did markedly increase ER $\alpha$ expression in response to ovariectomy $(P<0.01)$. By contrast, FLL treatment showed a trend toward increasing ER $\beta$ expression in OVX rats, but the differences did not reach the statistically significant level when compared to those of rats in the OVX control group.

Table 2 Serum levels of $E_{2}$ LH and FSH in the different groups of rats

\begin{tabular}{lllll}
\hline Groups & Number & $\mathrm{E}_{2}(\mathrm{pg} / \mathrm{ml})$ & $\mathrm{LH}(\mathrm{mUl} / \mathrm{ml})$ & $\mathrm{FSH}(\mathrm{mUl} / \mathrm{ml})$ \\
\hline Sham & 9 & $15.5975 \pm 5.0579^{*}$ & $2.1711 \pm 0.8571^{*}$ & $0.8411 \pm 0.3071^{*}$ \\
OVX & 9 & $6.65 \pm 2.3853$ & $3.8744 \pm 0.8100$ & $1.8837 \pm 0.3301$ \\
OVX+EV & 9 & $11.9755 \pm 1.0535^{*}$ & $2.5850 \pm 0.4829^{*}$ & $1.2087 \pm 0.1795^{*}$ \\
OVX + FLL & 9 & $6.8842 \pm 1.9301$ & $3.0455 \pm 0.5554^{*}$ & $1.4512 \pm 0.2801^{*}$ \\
\hline
\end{tabular}

${ }^{*}$ Compared with OVX group rats, ${ }^{*} P<0.05$ 


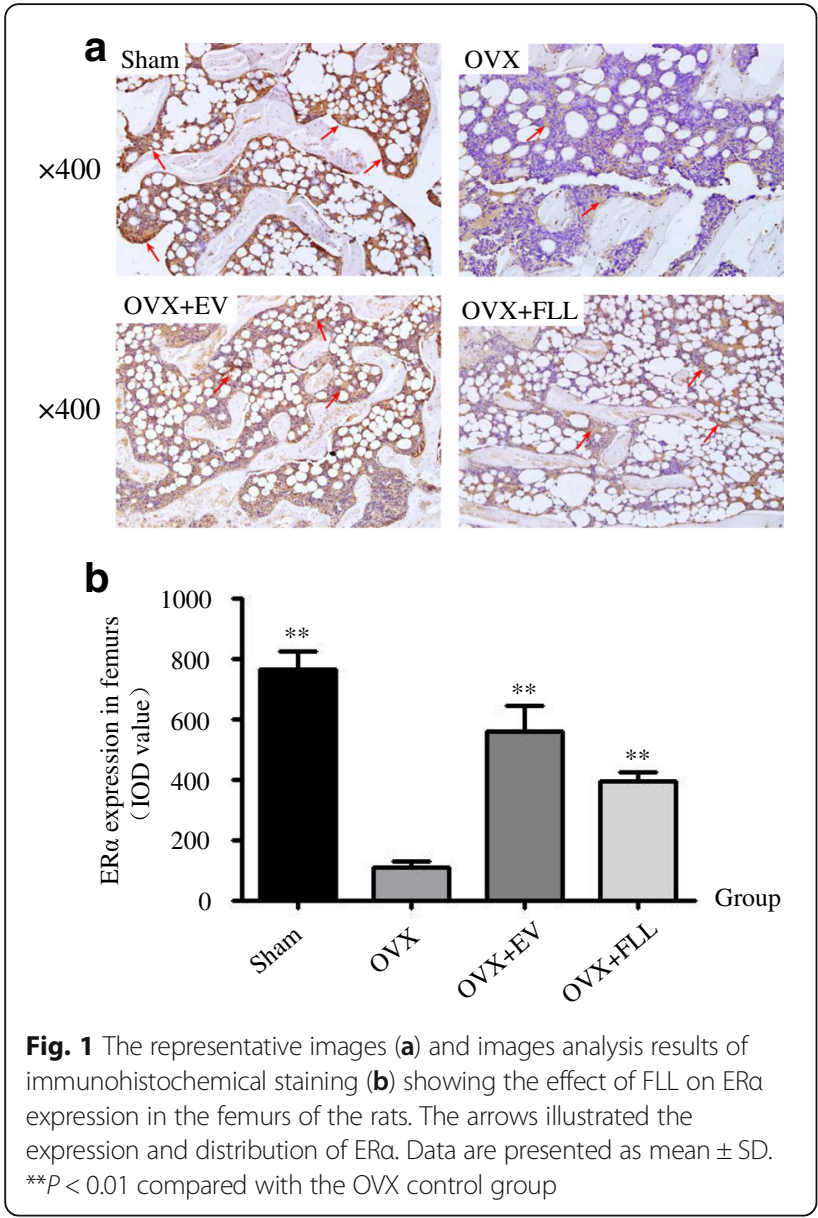

\section{Effects of FLL on the expressions of ERa and ER $\beta$ in the uteri of OVX rats}

As shown in Figs. 4 and 5, ER $\alpha$ and ER $\beta$ were mainly located in the endometrium and glandular epithelia cells, and were highly expressed in the uteri of rats in sham control group and EV treatment group compared to those of rats in the OVX control group as evaluated by immunohistochemical staining $(P<0.01)$. Further, FLL treatment did not increase ER $\alpha$ expression but did obviously increase ER $\beta$ expression in the uteri of the OVX rats $(P<0.05)$. These results were also further confirmed by western blot (Fig. 6).

\section{Discussion}

In the current study, we demonstrated that FLL treatment decreased serum LH and FSH levels but not increased serum $\mathrm{E}_{2}$ level in OVX rats. FLL did not increase uterus relative weight in response to ovarirectomy. In addition, FLL treatment significantly enhanced $E R \beta$ expression, but left no evident influence on ER $\alpha$ in uteri. Moreover, FLL treatment markedly enhanced ER $\alpha$ expression, but had no obvious effect on ER $\beta$ expression in the femurs and tibias. These results suggest that FLL

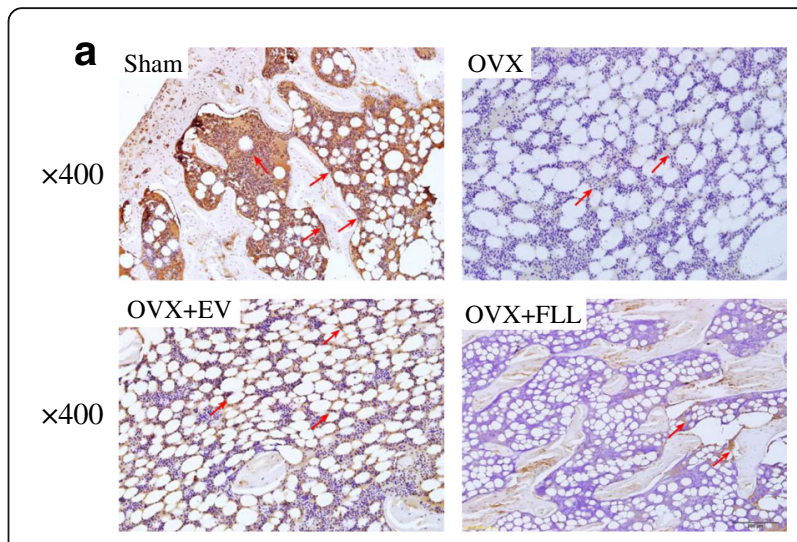

b

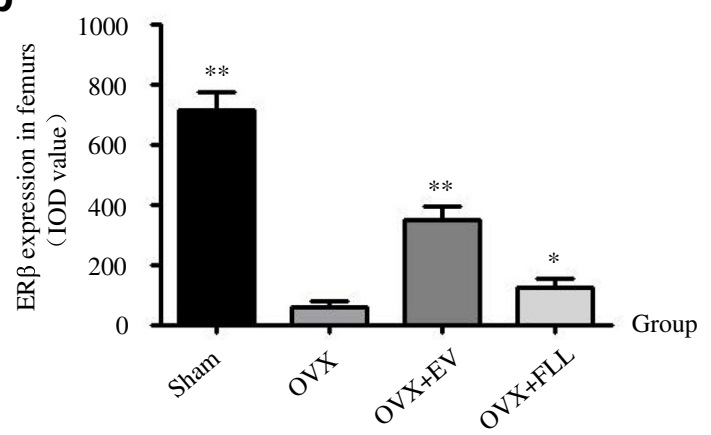

Fig. 2 The representative images (a) and images analysis results of immunohistochemical staining (b) showing the effect of FLL on ERß expression in the femurs of the rats. The arrows illustrated the expression and distribution of ER $\beta$. Data are presented as mean $\pm \mathrm{SD}$. ${ }^{*} P<0.05$ or ${ }^{* *} P<0.01$ compared with the OVX control group

may show different effects on ER expression in bones and uteri, which may contribute to uterus health during the treatment of osteoporosis.

Both ER $\alpha$ and ER $\beta$ are the main targets of estrogen and can be either coexistent or expressed alone in various tissues [17]. ER $\alpha$ is inclined to be found in the ovary, breast, hypophysis, paranephros, kidney and bone, while ER $\beta$ is highly concentrated in the granulosa cells of prostate and ovary, commonly expressed in ovary, lung, brain and testis, and less expressed in hypophysis and spinal cord $[18,19]$. In the reproductive system, ER $\alpha$ expression decreases gradually from the epithelial cells of vagina to those of oviduct $[20,21]$. In the uteri of OVX rats, the expression of ER $\beta$ are tremendously reduced and almost only ER $\alpha$ can be detected [22, 23]. Overexpression of ERa may lead to the hyperplasia of mammary glands and endometrial cells, and result in an increased risk of breast cancer and endometrial cancer [24]. In contrast, activation of ER $\beta$ never causes the relevant cell proliferation, instead, it has certain effects against cell proliferation [25]. In the current study, we found that FLL treatment did increase ER $\beta$ expression in the uteri though with no significant effect on ER $\alpha$ 


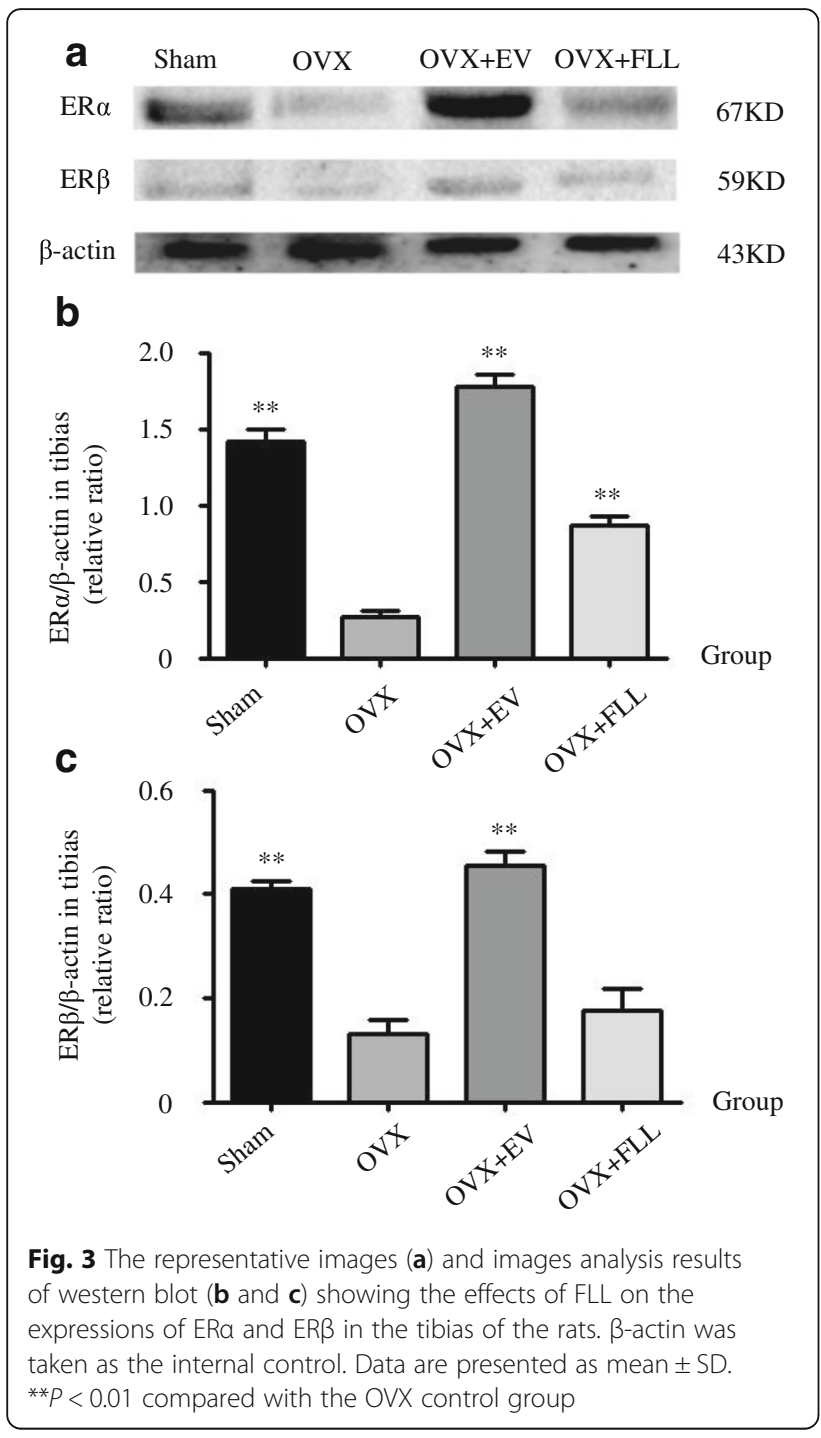

expression, which may contribute to maintain the uterus health during the management of osteoporosis. The results suggest that FLL may selectively enhance ER $\beta$ expression in uteri of OVX rats. As compared to other phytoestrogens with high affinities with ER $\alpha$, the application of FLL does not increase the risk of endometrial hyperplasia.

$E R \alpha$ and ER $\beta$ possess vast expressions and may antagonize each other in the bones and bone marrows $[26,27]$. Deletion of ER $\alpha$ in osteoblast or osteoclast impedes bone formation and strength accrual in female mice [28]. Inhibition of ER $\alpha$ (not ER $\beta$ ) expression in osteoclast promotes bone resorbing activity [29]. Deletion of ER $\alpha$ in osteoclast attenuates protective effect of estrogen on cancellous bone through increasing osteoclastogenesis. Furthermore, double deficiency of ER $\alpha$ and ER $\beta$ has similar reductions in BMD versus single deficiency of ER $\alpha$ in mice [30]. The results form clinical

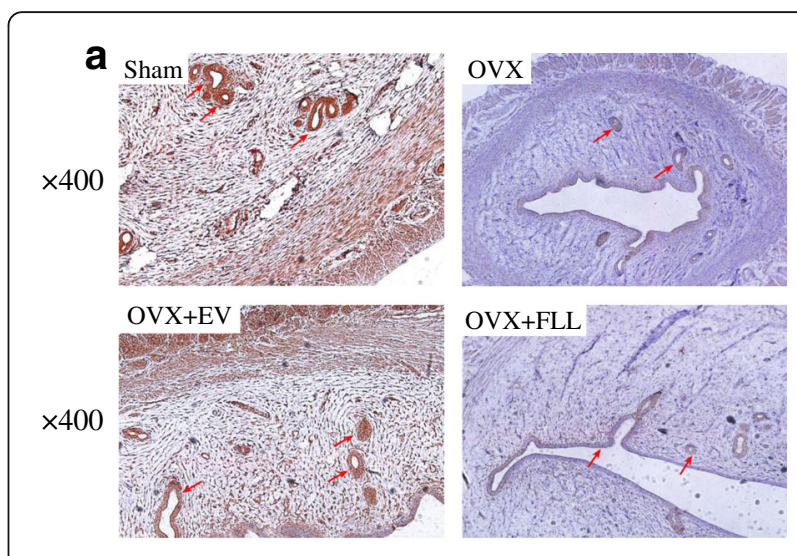

b

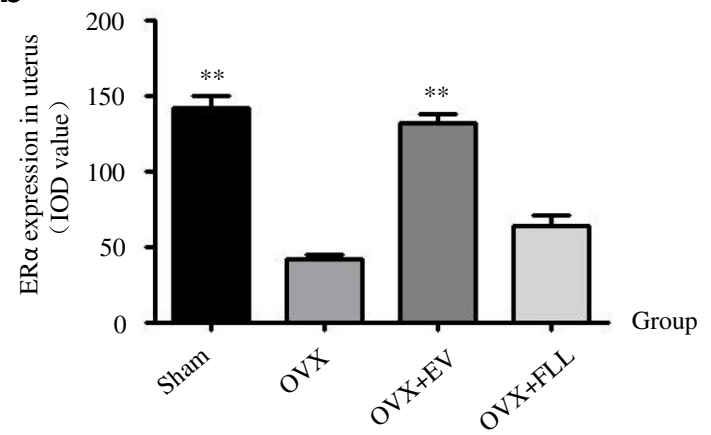

Fig. 4 The representative images (a) and images analysis results of immunohistochemical staining (b) showing the effect of FLL on ERa expression in the uteri of the rats. The arrows illustrated the expression and distribution of ERa. Data are presented as mean \pm SD. ${ }^{* *} P<0.01$ compared with the OVX control group

trials also support the notion that ER $\alpha$ (not ER $\beta$ ) plays a beneficial role in maintaining bone health in men [31]. In addition, the advantage of ER $\alpha$ over ER $\beta$ favors for bone formation and fracture healing in OVX rats [26]. These findings suggest that the protective effect of estrogen on BMD in trabecula may be practiced via ER $\alpha$. In conjunction with our current finding of an increase in ER $\alpha$ expression in rats of FLL treatment group and the results from our previous publication [14] as well as other groups $[15,30,32]$, the results indicate that FLL treatment may boost bone density through induction of ER $\alpha$ expression in OVX rats.

$E R \alpha$ and ER $\beta$ may play different roles in the bone metabolism and remodeling. These roles are different in some aspects yet interrelated in other aspects. Estrogen's effect on bones is likely to function through the mediation of ER $\alpha$. The two subtypes of ER may exist as a complementary relationship, in other words, when ER $\alpha$ exists, ER $\beta$ may weaken the transcriptional activation function of $E R \alpha$, and while $E R \alpha$ is absent, $E R \beta$ can partially replace some functions of ER $\alpha$. Selective agonist of $E R \alpha$ can entirely offset the influence of ovariectomy on uterus weight and BMD in the experimental rats $[7,19]$. 


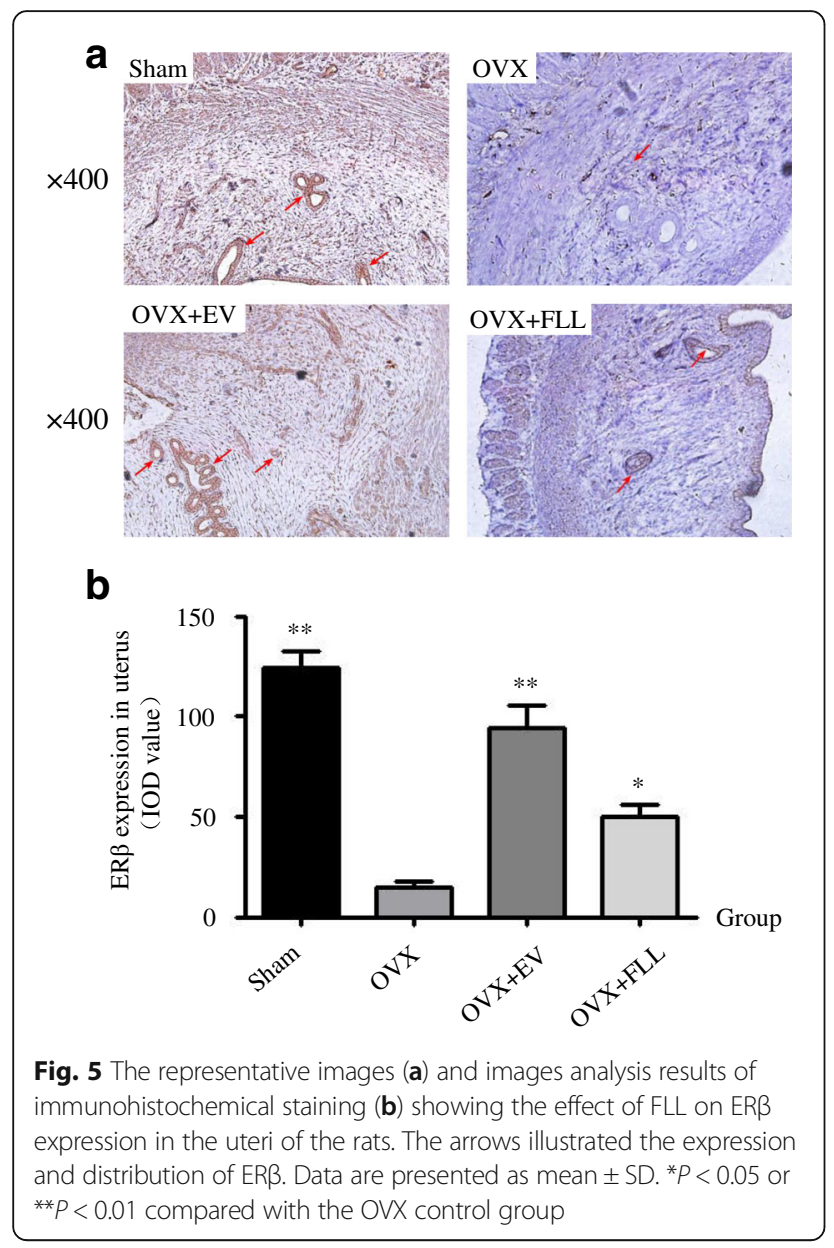

The findings of our current study here also show that aqueous extract of FLL could enhance ER $\alpha$ expression, and have no apparent influence on ER $\beta$ expression in the femurs and tibias of OVX rats.

In the current study, we found that FLL treatment significantly decreased the levels of LH and FSH but did not increase $E_{2}$ levels in OVX rats. Ovariectomy in rats results in a decrease in $E_{2}$ and an increase in $\mathrm{LH}$ and FSH [33, 34]. Deficiency of $E_{2}$ significantly promotes bone loss and aggravates uterus atrophy [34, 35]. Inhibition of FSH also impairs bone loss and further prevents $\mathrm{LH}$ release while the alteration does not play a dominant role in the development of osteoporosis [35]. In addition, high circulating FSH contributes to endometrial atrophy in mice [36]. Increased circulating LH may be associated with postmenopausal "hot flushes" [37]. The increase of FSH may contribute to uterus atrophy. The results suggest that FLL could alleviate postmenopausal vasomotor symptoms, which required further investigation.

In addition, we have demonstrated that FLL water extract mainly includes salidroside, ligustroflavon, acteoside, specnuezhenide, and oleuropein acid [38]. Currently, salidroside was demonstrated to bind to ER $\alpha$ in

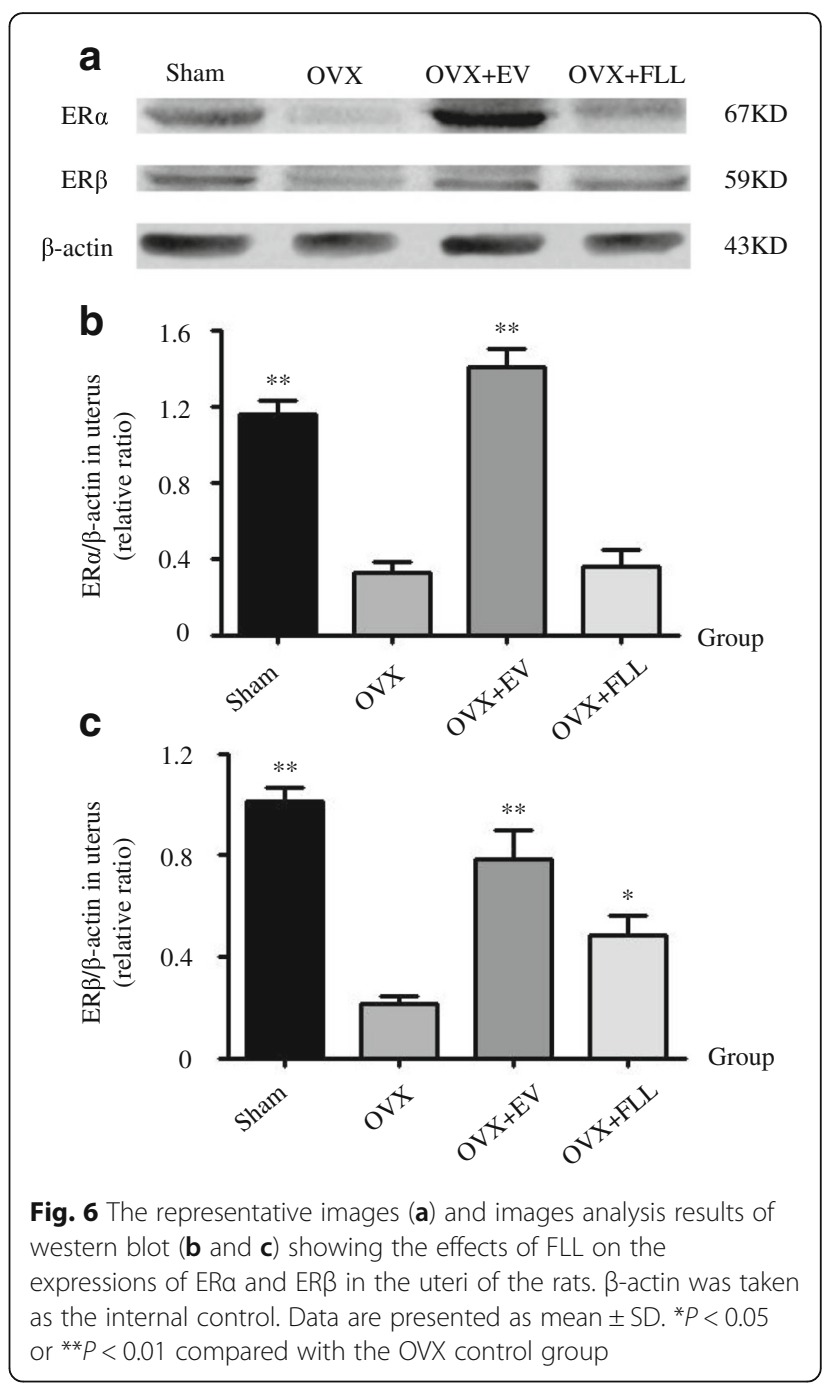

docking simulation assay [39]. So it is reasonable to deduce that salidroside may account for the estrogen-like effect of FLL in OVX rats. However, further studies are still needed to identify the contributions of each component in the FLL aqueous extract.

\section{Conclusion}

In conclusion, FLL treatment increases ER $\beta$ expression in uteri and strengthens ER $\alpha$ expression in the femurs and tibias as well as poses no risk of the increasing of uterus relative weight in OVX rats. In addition, our findings also demonstrate that FLL has the ability of coordinating LH and FSH levels in circulation, which may contribute to alleviate postmenopausal vasomotor symptoms. However, how FLL regulates ER expression in OVX rats still needs further investigation.

\section{Abbreviations}

BMD: Bone mineral density; BUCM: Beijing University of Traditional Chinese Medicine; DAB: Diaminobenzidine; $E_{2}$ : Estrogen;

EDTA: Ethylenediaminetetraacetic acid; EGTA: Ethyleneglycoltetraacetic acid; 
ER: Estrogen receptor; EV: Estradiol valerate; FLL: Fructus Ligustri Lucidi; FSH: Follicle-stimulating hormone; HRT: Hormone replacement therapy; IOD: Integral optical density; LH: Luteinizing hormone; OVX: Ovariectomized; PBS: Phosphate-buffered saline; TCM: Traditional Chinese medicine

\section{Acknowledgements}

Not applicable.

\section{Funding}

This study was supported by the Grants from the National Natural Science Foundation of China (No. 81573716, 81273995) and the 111 project of MOE (B07007) as well as Beijing Municipal Natural Science Foundation (7172126).

\section{Availability of data and materials}

The datasets used and/or analysed during the current study available from the corresponding author on reasonable request.

\section{Authors' contributions}

YQT and $C L$ designed and conducted most of animal experiments and drafted the manuscript. XJS, YiL and XTW conducted immunohistochemical experiments. YBG, LLW and RFM conducted western blot and analysed experimental results. JZN and MF interpreted the results. DWZ and YuL conceived the experiments and revised the manuscript. All authors have read and approved the final manuscript.

\section{Ethics approval}

All procedures in this study were performed in accordance with the "Guidelines for Experimental Animal Care and Use" from the Animal Care Committee of BUCM, Beijing, China. The protocol was approved by the Animal Care Committee of BUCM, Beijing, China.

\section{Consent for publication}

Not applicable.

\section{Competing interests}

The authors declare that they have no competing interests.

\section{Publisher's Note}

Springer Nature remains neutral with regard to jurisdictional claims in published maps and institutional affiliations.

\section{Author details}

${ }^{1}$ Traditional Chinese Medicine School, Beijing University of Chinese Medicine, Beijing 100029, People's Republic of China. ${ }^{2}$ Chinese Material Medica School, Beijing University of Chinese Medicine, Beijing 100029, People's Republic of China. ${ }^{3}$ The Research Institute of McGill University Health Center, Montreal, Quebec H4A 3J1, People's Republic of China. ${ }^{4}$ Diabetes Research Center, Beijing University of Chinese Medicine, Beijing 100029, People's Republic of China.

Received: 18 November 2016 Accepted: 15 March 2018

Published online: 02 April 2018

\section{References}

1. Kruger MC, Wolber FM: Osteoporosis: modern paradigms for last Century's bones. Nutrients 2016;8(6):376.

2. Lin $X$, Xiong D, Peng YQ, Sheng ZF, Wu XY, Wu XP, Wu F, Yuan LQ, Liao EY. Epidemiology and management of osteoporosis in the People's Republic of China: current perspectives. Clin Interv Aging. 2015:10:1017-33.

3. Cauley JA. Estrogen and bone health in men and women. Steroids. 2015; 99(Pt A):11-5.

4. Niu AQ, Xie $L$, Wang $H$, Zhu B, Wang SQ. Prediction of selective estrogen receptor beta agonist using open data and machine learning approach. Drug Des Devel Ther. 2016;10:2323-31.

5. Melville KM, Kelly NH, Surita G, Buchalter DB, Schimenti JC, Main RP, Ross FP, van der Meulen MC. Effects of deletion of ERalpha in osteoblast-lineage cells on bone mass and adaptation to mechanical loading differ in female and male mice. J Bone Miner Res. 2015;30(8):1468-80.

6. Macari S, Ajay SL, Wyatt A, Knowles P, Szawka RE, Garlet GP, Grattan DR, Dias GJ, Silva TA. Osteoprotective effects of estrogen in the maxillary bone depend on ERalpha. J Dent Res. 2016;95(6):689-96.
7. Matsushima H, Mori T, Ito F, Yamamoto T, Akiyama M, Kokabu T, Yoriki K, Umemura S, Akashi K, Kitawaki J. Anti-tumor effect of estrogen-related receptor alpha knockdown on uterine endometrial cancer. Oncotarget. 2016:7(23):34131-48.

8. Lin Z, Yin P, Reierstad S, O'Halloran M, Coon VJ, Pearson EK, Mutlu GM, Bulun SE. Adenosine A1 receptor, a target and regulator of estrogen receptoralpha action, mediates the proliferative effects of estradiol in breast cancer. Oncogene. 2010;29(8):1114-22.

9. Cvoro A, Paruthiyil S, Jones JO, Tzagarakis-Foster C, Clegg NJ, Tatomer D, Medina RT, Tagliaferri M, Schaufele F, Scanlan TS, et al. Selective activation of estrogen receptor-beta transcriptional pathways by an herbal extract. Endocrinology. 2007;148(2):538-47.

10. de Villiers TJ, Gass ML, Haines CJ, Hall JE, Lobo RA, Pierroz DD, Rees M. Global consensus statement on menopausal hormone therapy. Climacteric. 2013;16(2):203-4.

11. Cheng M, Wang Q, Fan Y, Liu X, Wang L, Xie R, Ho CC, Sun W. A traditional Chinese herbal preparation, Er-Zhi-wan, prevent ovariectomy-induced osteoporosis in rats. J Ethnopharmacol. 2011;138(2):279-85.

12. Zhang $Y$, Diao TY, Wang $L$, Che $C T$, Wong MS. Protective effects of water fraction of Fructus Ligustri Lucidi extract against hypercalciuria and trabecular bone deterioration in experimentally type 1 diabetic mice. J Ethnopharmacol. 2014;158 Pt A:239-45.

13. Lyu Y, Feng $X$, Zhao $P$, Wu Z, Xu H, Fang Y, Hou Y, Denney L, Xu Y, Feng $H$. Fructus Ligustri Lucidi (FLL) ethanol extract increases bone mineral density and improves bone properties in growing female rats. J Bone Miner Metab. 2014;32(6):616-26

14. Guo Y, Wang L, Ma R, Wang L, Yang M, Tang Y, Liu C, Zhu R, Liu H, Zhao D, et al. Effects of water extract from Fructus Ligustri Lucidi on bone structure and metabolism in ovariectomized rats. Chinese Tradit Herb Drugs. 2016;47:1155-62.

15. Guo Y, Ma R, Wang L, Liu H, Zhu R, Shi R, Zhao D, Mo F, Gao S, Zhang D. Research progress on effects and their mechanism of Ligustri Lucidi Fructus in treatment of osteoporosis. Chinese Trad Herb Drugs. 2016:47:851-6.

16. Li G, Zhang XA, Zhang JF, Chan CY, Yew DT, He ML, Lin MC, Leung PC, Kung HF. Ethanol extract of Fructus Ligustri Lucidi promotes osteogenesis of mesenchymal stem cells. Phytother Res. 2010;24(4):571-6.

17. Wong KC, Lee KS, Luk HK, Wan HY, Ho CK, Zhang Y, Wong MS. Er-xian decoction exerts estrogen-like osteoprotective effects in vivo and in vitro. Am J Chin Med. 2014;42(2):409-26.

18. Paterni I, Granchi C, Katzenellenbogen JA, Minutolo F. Estrogen receptors alpha (ERalpha) and beta (ERbeta): subtype-selective ligands and clinical potential. Steroids. 2014;90:13-29.

19. Harris HA, Katzenellenbogen JA, Katzenellenbogen BS. Characterization of the biological roles of the estrogen receptors, ERalpha and ERbeta, in estrogen target tissues in vivo through the use of an ERalpha-selective ligand. Endocrinology. 2002;143(11):4172-7.

20. Couse JF, Lindzey J, Grandien K, Gustafsson JA, Korach KS. Tissue distribution and quantitative analysis of estrogen receptor-alpha (ERalpha) and estrogen receptor-beta (ERbeta) messenger ribonucleic acid in the wild-type and ERalpha-knockout mouse. Endocrinology. 1997;138(11):4613-21.

21. Baranda-Avila N, Cardoso-Rangel ME, Cerbon M, Camacho-Arroyo I, Mendoza-Rodriguez CA, Villasenor-Gaona H, Anzaldua-Arce SR. Differential expression of estrogen receptor alpha gene in the ampullae and isthmus regions of the rabbit oviduct during early pregnancy. Anim Reprod Sci. 2010;121(3-4):286-93.

22. Cevik O, Akpinar H, Oba R, Cilingir OT, Ozdemir ZN, Cetinel S, Yoldemir T. The effect of Momordica charantia intake on the estrogen receptors ESRalpha/ESRbeta gene levels and apoptosis on uterine tissue in ovariectomy rats. Mol Biol Rep. 2015:42(1):167-77.

23. Sims NA, Dupont S, Krust A, Clement-Lacroix P, Minet D, Resche-Rigon M, Gaillard-Kelly M, Baron R. Deletion of estrogen receptors reveals a regulatory role for estrogen receptors-beta in bone remodeling in females but not in males. Bone. 2002;30(1):18-25.

24. Christenson ES, Jiang $X$, Kagan R, Schnatz P. Osteoporosis management in post-menopausal women. Minerva Ginecol. 2012;64(3):181-94.

25. Nilsson S, Koehler KF, Gustafsson JA. Development of subtype-selective oestrogen receptor-based therapeutics. Nat Rev Drug Discov. 2011;10(10): 778-92.

26. Chow SK, Leung KS, Qin L, Wei F, Cheung WH. Callus formation is related to the expression ratios of estrogen receptors-alpha and -beta in ovariectomyinduced osteoporotic fracture healing. Arch Orthop Trauma Surg. 2014; 134(10):1405-16. 
27. Khalid AB, Krum SA. Estrogen receptors alpha and beta in bone. Bone. 2016; 87:130-5.

28. Melville KM, Kelly NH, Khan SA, Schimenti JC, Ross FP, Main RP, van der Meulen MC. Female mice lacking estrogen receptor-alpha in osteoblasts have compromised bone mass and strength. J Bone Miner Res. 2014;29(2):370-9.

29. Mano H, Hakeda Y, Kumegawa M. Estrogen directly down-regulates the bone-resorbing activity of mature osteoclasts through nuclear estrogen receptor alpha. Cytotechnology. 2001;35(1):17-23.

30. McCauley LK, Tozum TF, Kozloff KM, Koh-Paige AJ, Chen C, Demashkieh M, Cronovich H, Richard V, Keller ET, Rosol TJ, et al. Transgenic models of metabolic bone disease: impact of estrogen receptor deficiency on skeletal metabolism. Connect Tissue Res. 2003;44(Suppl 1):250-63.

31. Khosla S, Riggs BL, Atkinson EJ, Oberg AL, Mavilia C, Del MF, Melton LR, Brandi ML. Relationship of estrogen receptor genotypes to bone mineral density and to rates of bone loss in men. J Clin Endocrinol Metab. 2004; 89(4):1808-16

32. Li X, Song QS, Wang JY, Leng HJ, Chen ZQ, Liu ZJ, Dang GT, Song CL Simvastatin induces estrogen receptor-alpha expression in bone, restores bone loss, and decreases ERalpha expression and uterine wet weight in ovariectomized rats. J Bone Miner Metab. 2011;29(4):396-403.

33. Cen J, Zhang H, Liu Y, Deng M, Tang S, Liu W, Zhang Z. Anti-aging effect of estrogen on telomerase activity in ovariectomised rats-animal model for menopause. Gynecol Endocrinol. 2015;31(7):582-5.

34. Xu Y, Ding J, Ma XP, Ma YH, Liu ZQ, Lin N. Treatment with Panax ginseng antagonizes the estrogen decline in ovariectomized mice. Int J Mol Sci. 2014;15(5):7827-40.

35. Rouach V, Katzburg S, Koch Y, Stern N, Somjen D. Bone loss in ovariectomized rats: dominant role for estrogen but apparently not for FSH. J Cell Biochem. 2011;112(1):128-37.

36. Zhang D, Li J, Xu G, Zhang R, Zhou C, Qian Y, Liu Y, Chen L, Zhu B, Ye X et al. Follicle-stimulating hormone promotes age-related endometrial atrophy through cross-talk with transforming growth factor beta signal transduction pathway. Aging Cell. 2015;14(2):284-7.

37. Seidlova-Wuttke D, Hesse O, Jarry H, Christoffel V, Spengler B, Becker T, Wuttke W. Evidence for selective estrogen receptor modulator activity in a black cohosh (Cimicifuga racemosa) extract: comparison with estradiol17beta. Eur J Endocrinol. 2003;149(4):351-62.

38. Wang L, Ma R, Guo Y, Sun J, Liu H, Zhu R, Liu C, Li J, Li L, Chen B, et al. Antioxidant effect of Fructus Ligustri Lucidi aqueous extract in Ovariectomized rats is mediated through Nox4-ROS-NF-kappaB pathway. Front Pharmacol. 2017;8:266.

39. Zhang J, Kasim V, Xie YD, Huang C, Sisjayawan J, Dwi AA, Yan XS, Wu XY, Liu CP, Yang L, et al. Inhibition of PHD3 by salidroside promotes neovascularization through cell-cell communications mediated by muscle-secreted angiogenic factors. Sci Rep. 2017;7:43935.

\section{Submit your next manuscript to BioMed Central and we will help you at every step:}

- We accept pre-submission inquiries

- Our selector tool helps you to find the most relevant journal

- We provide round the clock customer support

- Convenient online submission

- Thorough peer review

- Inclusion in PubMed and all major indexing services

- Maximum visibility for your research

Submit your manuscript at www.biomedcentral.com/submit

) Biomed Central 